\title{
Патогенетичні аспекти рубцевих гриж у хворих на морбідне ожиріння
}

\author{
I. M. TODUROV, L. S. BILIANSKYI, S. V. KOSIUKHNO, O. V. PEREKHRESTENKO, O. O. KALASHNIKOV \\ National Institute of Surgery and Transplantology by O. O. Shalimov of NAMS of Ukraine
}

\section{PATHOGENIC ASPECTS OF SEAM HERNIAS IN PATIENTS WITH MORBID OBESITY}

\begin{abstract}
У роботі проведено вивчення окремих ланок патогенезу рубцевих гриж передньої черевної стінки у хворих на морбідне ожирінн після баріатричних оперативних втручань. Проаналізовано вплив фактора внутрішньочеревного тиску на розвиток гриж черевної стінки, обгрунтовано доцільність диференційованого профілактичного протезування післяопераційного доступу в означеної категорії хворих.

The article adduces the research of some pathogenesis links of seam hernias of anterior abdominal wall in patients with morbid obesity after bariatric surgical interferences. It was analyzed the influence of the factor of intraabdominal pressure on the development of abdominal wall hernias, grounded the expediency of differentiated prophylactic prosthesis of post-operative access in this category of patients.
\end{abstract}

Постановка проблеми і аналіз останніх досліджень та публікацій. Проблема профілактики післяопераційних рубцевих гриж передньої черевної стінки виникла одночасно з народженням хірургіï, набуває нових аспектів у процесі їі розвитку, а герніологія і дотепер залишається одним із найбільш актуальних розділів абдомінальної хірургії. Незважаючи на постійне вдосконалення способів зашивання передньої черевної стінки та використання сучасних шовних матеріалів, число післяопераційних рубцевих гриж залишається досить значним і не має істотної тенденції до зменшення $[1,6]$.

Від 2 до 15 \% лапаротомій, виконаних навіть у високоспеціалізованих клініках із використанням сучасних шовних матеріалів, призводять до утворення рубцевих вентральних гриж, а у хворих на морбідне ожиріння цей відсоток збільшується майже до $30 \%[2,3]$.

Протягом останніх років проводились наукові дослідження, спрямовані на поглиблене вивчення закономірностей патогенезу гриж. Деякі дослідники вважають, що в патогенезі рубцевих гриж живота значну роль відіграють неадекватна корекція супутньої патології, онкологічний статус, порушення процесів тканинного обміну та колагеногенезу, порушення регенераторних процесів, підвищення внутрішньочеревного тиску (ВЧТ), ожиріння та ін. $[5,8]$, що приводить до асинхронного виникнення структурно-метаболічних порушень апоневроза 3 утворенням дефектів у ділянці піхов прямих м'язів і білої лінії живота. Тобто, причини утворення післяопераційних гриж мають багатофакторний характер $[1,4,9]$.

3 огляду на інтенсивний розвиток баріатричної хірургії, проблеми профілактики грижоутворення i вивчення окремих ланок патогенезу рубцевих гриж у хворих на морбідне ожиріння набувають особливої актуальності та важливості $[2,7]$.

Мета роботи: провести аналіз патогенетичних особливостей формування рубцевих гриж у хворих на морбідне ожиріння та обгрунтувати тактичні принципи профілактики дефектів черевної стінки після баріатричних оперативних втручань.

Матеріали і методи. У дослідження включено 53 хворих на морбідне ожиріння (26 (49,1 \%) чоловіків та 27 (50,9\%) жінок віком від 16 до 63 років, у середньому $(44,3 \pm 8,9)$ року), яким за період з 2010 до 2013 року виконано баріатричні оперативні втручання (39 (73,6 \%) пацієнтам - біліопанкреатичне шунтування з вимкненням дванадцятипалої кишки за Hess-Marceau (БПШ із ДВ), 14 (26,4 \%) хворим - sleeve-гастректомію). Оперативні втручання виконано з верхньосерединного лапаротомного доступу. 43 (81,1 \%) пацієнтам виконано первинне зашивання лапаротомної рани безперервним швом PDS-0, 10 (18,9 \%) хворим - превентивну алоплас- 
тику черевної стінки з використанням біоматеріалу GORE-TEX DualMesh за методикою "intraabdominal on lay".

У передопераційному періоді всім хворим виконували комплекс обстежень, спрямованих на виявлення супутніх захворювань та порушень, характерних для метаболічного синдрому, визначали масу тіла, індекс маси тіла (IMT), надлишок маси тіла (НМТ).

У всіх хворих, які були включені в дослідження, показаннями до виконання біліопанкреатичного шунтування з вимкненням дванадцятипалої кишки були наявність морбідного ожиріння (IMT понад $40 \kappa г / \mathrm{M}^{2}$ ), а також супутніх захворювань та порушень обміну речовин, патогенетично пов'язаних із надлишковою масою тіла.

Моніторинг ВЧТ проводили непрямим методом за допомогою трансвезикальної тензометрії згідно 3 узгодженими рекомендаціями WSACS.

Перше вимірювання ВЧТ виконували безпосередньо перед оперативним втручанням на операційному столі після інтубації хворого.

Під внутрішньочеревною гіпертензією розуміли стійке чи рецидивне підвищення ВЧТ понад 12 мм рт. ст. (1,59 кПа), що реєстрували протягом трьох послідовних вимірювань, інтервал між якими складав 4 год.

Хворих обстежено повторно через 3, 6, 9, 12 міс. після виконання баріатричної операції.

Результати досліджень та їх обговорення. Маса тіла пацієнтів до операції перебувала в діапазоні від 107 до 215 кг, у середньому $(153,9 \pm 27,6)$ кг. Надлишок маси тіла становив від 51 до 141 кг (у середньому - $(87,7 \pm 23,4)$ кг). ІМТ становив від 40 до 75,4 кг $/ \mathrm{M}^{2}$, із середнім значенням показника $(52,4 \pm 7,7) \kappa г / \mathrm{M}^{2}$.

При проведенні моніторингу ВЧТ встановлено, що у всіх хворих, включених у дослідження, ініціальний рівень вказаного показника перевищував граничне для діагностики синдрому ВЧГ значення 12 мм рт. ст. (1,59 кПа).

Залежно від величини ініціального рівня ВЧТ всіх хворих, включених у дослідження, було розподілено на 2 групи. До 1-ї групи включено 30 (56,7 \%) пацієнтів із морбідним ожирінням, вихідний рівень ВЧТ у яких перебував у межах 12-15 мм рт. ст. $(1,59-1,99$ кПа), середнє значення $(13,1 \pm 1,5)$ мм рт. ст. $((1,74 \pm 0,19)$ кПа), до 2-ї групи - $23(43,3 \%)$ хворих 3 морбідним ожирінням з вихідним рівнем ВЧТ понад 15 мм рт. ст. $(1,99$ кПа), середнє значення $(16,5 \pm 1,7)$ мм рт. ст. $((2,19 \pm 0,22)$ кПа).

Встановлено, що між показником IMТ та рівнем ВЧТ існує прямо пропорційний статистично значимий кореляційний взаємозв' язок - при збільшенні значення IMТ спостерігається зростання вихідного рівня ВЧТ $-r=0,569(p=0,0037)$.

Післяопераційні рубцеві грижі було діагностовано у $14(26,4 \%)$ хворих. Із них у $12(85,7 \%)$ пацієнтів дефекти лапаротомного доступу було виявлено в строки від 3 до 9 міс. після виконання баріатричного оперативного втручання, у 2 (14,3\%) хворих рубцеві післяопераційні грижі виявлено протягом 2-го року після операції.

При цьому в 1-й групі хворих рубцеві післяопераційні грижі було діагностовано у 3 (10\%) пацієнтів, тоді як у 2-й групі-у 11 (47,8 \%) хворих. Вищезазначена різниця досягла статистичноїзначимості $(\mathrm{p}<0,05)$.

Враховуючи вищевказані результати, в подальшому відносно 10 (18,8 \%) хворих 2-ї групи нами було застосовано розроблену в клініці тактику превентивного алопротезування лапаротомного доступу з використанням біоматеріалу GORE-TEX DualMesh за методикою "intra-abdominal on lay". У термін спостереження до 1-го року виникнення грижового дефекту в жодного з вказаних пацієнтів ми не спостерігали.

Ускладнень, пов'язаних з імплантацією біоматеріалу GORE-TEX DualMesh, абдомінального компартмент-синдрому та летальних випадків не було.

Отримані результати дослідження не лише засвідчили високий відсоток грижоутворення у хворих на морбідне ожиріння після баріатричних оперативних втручань, а й підтвердили необхідність моніторингу ВЧТ та доцільність застосування тактики диференційованого превентивного протезування черевної стінки в означеної категорії хворих.

Висновки. 1. Ризик утворення дефектів черевної стінки у хворих на морбідне ожиріння після баріатричних оперативних втручань значимо вищий у групі пацієнтів з ініціальним рівнем внутрішньочеревного тиску понад 15 мм рт. ст. (1,99 кПа).

2. Превентивне диференційоване алопротезування лапаротомного доступу після виконання баріатричних оперативних втручань із використанням біоматеріалу GORE-TEX DualMesh за методикою "intra-abdominal on lay" є високоефективним, безпечним та патогенетично обгрунтованим методом профілактики післяопераційних рубцевих гриж у хворих на морбідне ожиріння. 


\section{СПИСОК ЛІТЕРАТУРИ}

1. Биомеханическая концепция патогенеза послеоперационных вентральных грыж / В. И. Белоконев, С. Ю. Пушкин, Т. А. Федорина [и др.] // Вестн. хирургии. - 2000. - № 5. - С. 23-29.

2. Comparison of Early and Late Complications after Various Bariatric Procedures: Incidence and Treatment During 15 Years at a Single Institution / G. Skroubis, S. Karamanakos, G. Sakellaropoulos [et al.] // World J. Surg. - 2011. - Vol. 35. P. 93-101.

3. Does Prophylactic Biologic Mesh Placement Protect Against the Development of Incisional Hernia in High-risk Patients? O. H. Llaguna, D. V. Avgerinos, P. Nagda [et al.] // World J. Surg. 2011. - Vol. 35. - P. 1651-1655.

4. Intra-abdominal pressure: a reliable criterion for laparostomy closure? / A. Schachtrupp, J. Hoer, C. Tons [et al.] // Hernia. 2002. - Vol. 6, N 3. - P. 102-107.
5. Lambert G. Intra-abdominal pressure in the morbidly obese/ G. Lambert, S. Marceau, R. A. Forse //Obes. Surg.- 2005. Vol.15. - P. 1225-1232.

6. Long-term results of polyglactin mesh for the prevention of incisional hernias in obese patients / A. Pans, P. Elen, W. Dewe [et al.] // World J. Surgery - 1998 - Vol. 22. - P. 479-483.

7. Robrecht H. G. G. Van Hee. Biliopancreatic Diversion in the Surgical Treatment of Morbid Obesity / Robrecht H.G.G. Van Hee // World J. Surg. - 2004. - Vol. 28. - P. 435-444.

8. Sugerman H. J. Effects of increased intra-abdominal pressure in severe obesity / H. J. Sugerman // Surg. Clin. North. Am. 2001. - Vol. 81. - P. $1063-1075$.

9. What is normal intra-abdominal pressure? / N. C. Sanchez, P. L. Tenofsky, J. M. Dort [et al.] // Am. Surg. -2001. - Vol. 67. P. 243-248.

Отримано 09.01.13 